\title{
A simple ligation-based method to increase the information density in sequencing reactions used to deconvolute nucleic acid selections
}

\author{
JESSICA L. CHILDS-DISNEY ${ }^{\mathbf{1}}$ and MATTHEW D. DISNEY \\ Department of Chemistry and The New York State Center for Excellence in Bioinformatics and Life Sciences, \\ University at Buffalo, Buffalo, New York 14260, USA
}

\begin{abstract}
Herein, a method is described to increase the information density of sequencing experiments used to deconvolute nucleic acid selections. The method is facile and should be applicable to any selection experiment. A critical feature of this method is the use of biotinylated primers to amplify and encode a BamHI restriction site on both ends of a PCR product. After amplification, the PCR reaction is captured onto streptavidin resin, washed, and digested directly on the resin. Resin-based digestion affords clean product that is devoid of partially digested products and unincorporated PCR primers. The product's complementary ends are annealed and ligated together with T4 DNA ligase. Analysis of ligation products shows formation of concatemers of different length and little detectable monomer. Sequencing results produced data that routinely contained three to four copies of the library. This method allows for more efficient formulation of structure-activity relationships since multiple active sequences are identified from a single clone.
\end{abstract}

Keywords: SELEX; aptamers; selection; RNA; DNA

\section{INTRODUCTION}

Systematic evolutions of ligands by exponential enrichment (SELEX) (Tuerk and Gold 1990) and selections are powerful and general techniques to identify members of nucleic acid libraries with a desired activity. Activity can be defined as binding to ligands as in the case of selections (Ellington and Szostak 1990; Jenison et al. 1994), performing a chemical reaction (Robertson and Joyce 1990), or some other selectable property. SELEX experiments have been used to study the origins of life (Szostak et al. 2001), as analytical tools (Seetharaman et al. 2001; Hartig et al. 2002), in the development of therapeutics (Gold 2002), and in reprogramming the genetic code (Bessho et al. 2002). Single rounds of nucleic acid selection have also been used to identify members of RNA structure libraries that have interesting thermodynamic properties from temperature

\footnotetext{
${ }^{1}$ Present address: Canisius College, Department of Chemistry, 2001 Main Street, Buffalo, NY 14208, USA.

Reprint requests to: Matthew D. Disney, Department of Chemistry and The New York State Center for Excellence in Bioinformatics and Life Sciences, University at Buffalo, 657 Natural Sciences Complex, Buffalo, NY 14260, USA; e-mail: mddisney@buffalo.edu; fax: (716) 645-6963.

Article published online ahead of print. Article and publication date are at http://www.rnajournal.org/cgi/doi/10.1261/rna.576908.
}

gradient gel electrophoresis experiments (Bevilacqua and Bevilacqua 1998; Shu and Bevilacqua 1999; Nakano et al. 2002; Proctor et al. 2002). In each type of selection experiment, an ensemble of active sequences and/or structures is isolated. In order to accurately determine structureactivity relationships, a large number of active members must be identified via sequencing (Sanger 1981). For laboratories with limited resources, however, sequencing a large subset of clones can be cost prohibitive. This is especially true for selection experiments that identify many active sequences.

DNA sequencers available in core facilities at most universities routinely sequence $1 \mathrm{~kb}$ of DNA in a single experiment. Most selections, however, are deconvoluted by sequencing only 10-40 nucleotides (nt). A more efficient approach would be to develop methods to identify more than one active library member per sequencing run to use more of the $1-\mathrm{kb}$ sequencing limit. For example, a library containing 10 randomized nucleotides would require cloning and sequencing of 40 nucleotides since $\sim 15$ nt are needed for primer binding sites on both sides of the randomized region in the reverse transcriptase-polymerase chain reaction (RT-PCR). Thus, the maximum number of inserts that could be sequenced from one clone is $\sim 20$, though in practice it is likely to be less considering most 
Escherichia coli strains remove large tandem repeats through recombination events (Albertini et al. 1982; Jones et al. 1982). Clearly, the number of sequences identified decreases as the length of the randomized region increases. A method that can identify multiple active sequences from one clone may decrease the costs of deconvoluting selection experiments and would facilitate a more efficient formulation of structure-activity relationships.

Herein, we describe a method to increase the information density contained in sequencing reactions by ligating together multiple copies of selected library members. Key features are the incorporation of two copies of the same restriction endonuclease site in the PCR product and the use of two biotinylated primers. Biotinylated primers are used to capture the PCR product and unincorporated primers onto streptavidin resin. Resin-supported restriction digestion releases only doubly cut PCR products, while excess primers and singly cut products remain resin-bound. The clean doubly cut PCR products freed from the resin contain complementary ends that are ligated with T4 DNA ligase to form concatemers that are then cloned and sequenced (Fig. 1). By using this method, 3.5 active sequences can be identified per clone on average.

\section{RESULTS AND DISCUSSION}

We designed and synthesized an RNA library that displays a $3 \times 3$-nt internal loop random region embedded in a hairpin cassette (Fig. 1; Bevilacqua and Bevilacqua 1998; Childs-Disney et al. 2007). The library was amplified by RT-PCR with 5'-biotinylated primers designed to incorporate BamHI restriction sites flanking both sides of the random region (Fig. 1). After amplification, complementary ends were created by digestion with BamHI. The crude reaction was either (1) incubated with streptavidin resin to capture both the PCR product and unincorporated primers

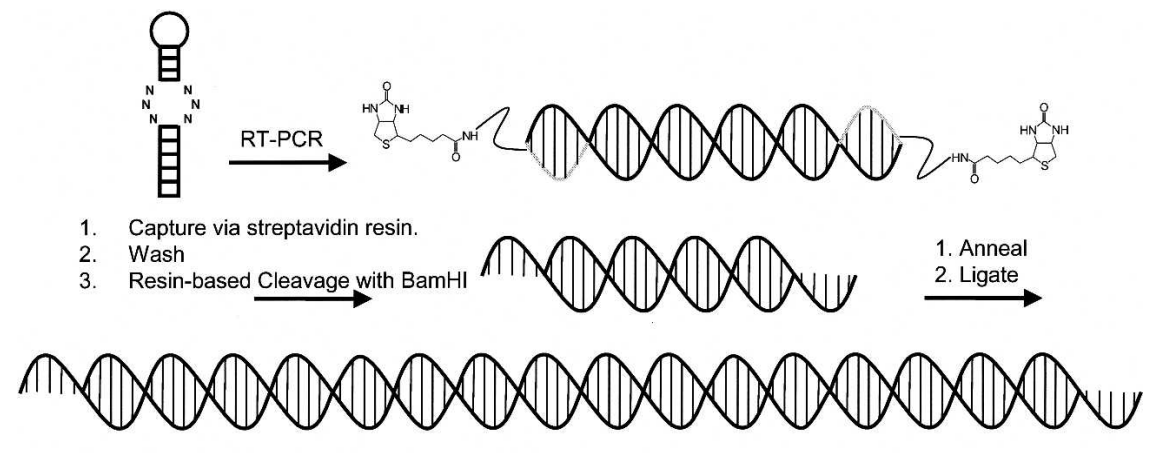

FIGURE 1. Schematic of a method to increase information density in sequencing experiments. A nucleic acid library (random region is shown schematically where $\mathrm{N}$ is any nucleotide) is amplified with two biotinylated primers that encode for the same restriction site on the $5^{\prime}$ and $3^{\prime}$ ends (schematically indicated in gray). After capture onto streptavidin resin and restriction digestion, individual library members are ligated together and cloned into a vector. and then digested with BamHI or (2) digested with BamHI in solution followed by capture of cleaved ends and unincorporated primers onto the resin. Previous reports have used streptavidin to isolate ssDNA from PCR products, which were separated by gel electrophoresis (Pagratis 1996) and as part of a method to create concatemers to analyze gene expression, termed SAGE (Velculescu et al. 1995).

In the first case, the crude PCR reaction was incubated with streptavidin resin, and then the resin was washed to remove unbound contaminants (such as NTPs and Taq DNA polymerase). Incubation with BamHI releases only the doubly cut PCR product from the resin (Fig. 2). No primer, cleaved ends, or singly cut products were detectable. Therefore, this resin-based protocol provides an easy method to quickly remove contaminants and primers from PCR reactions, singly cut PCR products, and cleaved ends from restriction digestions. In the second case, the streptavidin resin captured cleaved ends, unincorporated primers, and singly cut products after restriction digestion of the RT-PCR products. As discussed below, however, digested products produced using this method were not as suitable for downstream assays as were the RT-PCR products that were captured onto resin and then digested. This is likely due to the presence of contaminating PCR reaction components, which are removed in the other procedure during the first step.

The doubly digested RT-PCR products from both procedures were annealed separately and the monomers ligated together with T4 DNA ligase. As shown in Figure 3, when the RT-PCR product was digested off the resin, almost all monomer was ligated together to form concatemers of different sizes. On average, the most abundant product sizes range from 200 to $1000 \mathrm{bp}$, corresponding to ligation of three to 16 monomers, and the majority of the concatemers correspond to five to 12 ligated monomers. There are also dimers and trimers present in the reaction. Thus, this resin-based protocol does not require an additional separate clean-up step to remove monomer and can be directly cloned. We also found that the minimum optimal amount of DNA is $1.25 \mu \mathrm{g}$ in $20 \mu \mathrm{L}$; however, large concatemers (ligation of up to eight monomers) were also observed from as little as $150 \mathrm{ng}$ of DNA in $20 \mu \mathrm{L}$. The amount of monomer increases from $<0.5 \%$ for 1.25 $\mu \mathrm{g}$ of DNA in the concatenation reaction to $2.5 \%$ for $150 \mathrm{ng}$ of DNA.

In contrast, less efficient ligation was seen for the RT-PCR product that was digested in solution and then incubated with the streptavidin resin to remove cleaved ends, unincorporated primers, and singly cut RT-PCR products. Monomer and short concatemers, with the 


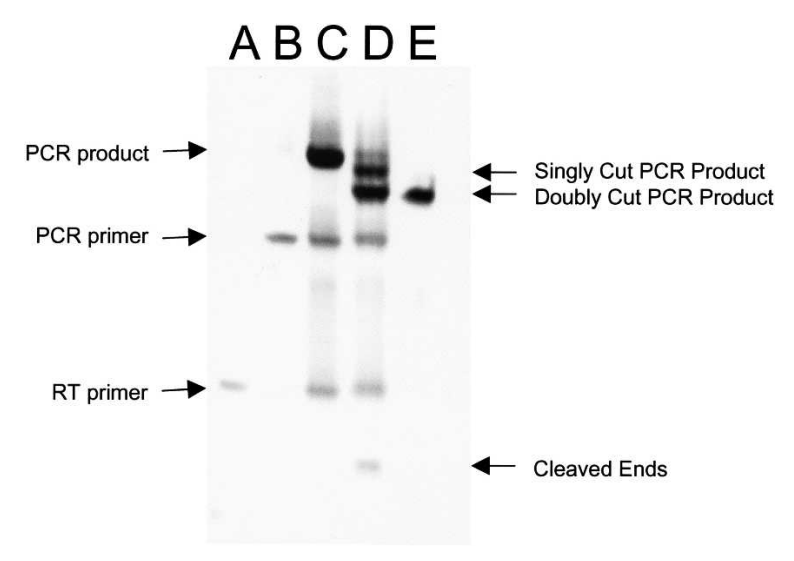

FIGURE 2. Analysis of BamHI restriction digestion of biotinylated RT-PCR product off of streptavidin resin. Lanes: $(A)$ biotinylated RT primer; $(B)$ biotinylated PCR primer; $(C)$ crude RT-PCR reaction; $(D)$ crude in solution restriction digestion with BamHI; (E) DNA eluted from resin-supported restriction digestion with BamHI.

largest being a trimer, were observed. The difference in these results are most likely due to the higher purity of product obtained from resin-based cleavage because the resin is washed after capturing to remove PCR reaction components.

The ligation reaction that afforded large concatemers (Fig. 3) was then cloned into pGEM T vector. This vector contains dangling Ts that pair with nontemplated As added by Taq DNA polymerase. Since the concatenated products have BamHI sticky ends on both the $5^{\prime}$ and $3^{\prime}$ ends, the ends were filled in using Taq DNA polymerase and nontemplated As added by addition of $1 \mathrm{mM}$ of dATP. Ligation into pGEM T vector was efficient, and all white colonies screened after transformation contained concatemers. Several of the isolated plasmids were PCR amplified using M13 primers that recognize regions flanking the multiple cloning site, allowing the size of the insert to be determined prior to submission for DNA sequencing (Fig. 4). PCR products of sizes consistent with concatemer formation were observed for all of the clones screened. Furthermore, multiple copies ( 3.5 on average) of the original library were inserted into each clone that was sequenced (Fig. 4).

In summary, we have developed a method to increase the information density in DNA sequencing reactions used to identify active nucleic acids from selection experiments. Implementing this technique should be applicable to any nucleic acid selection, because any restriction site can be incorporated into PCR primers that bind to cassette nucleotides outside of the random regions. A restriction digestion and biotin capture method was developed to quickly remove cleaved ends that can prematurely terminate ligations. Fewer clones need to be sequenced using our method than using one clone-one sequence technology. With a large number of bound sequences, the ligation approach described here would prove useful to facilitate a more accurate definition of structure-activity relationships.

\section{MATERIALS AND METHODS}

\section{General methods}

Nanopure water was used in all experiments. All solutions for buffers were prepared with DEPC-water to ensure the absence of nucleases. DNA oligonucleotides were purchased from Integrated DNA Technologies (IDT). Streptavidin resin was from Pierce. T4 DNA ligase and BamHI were purchased from New England BioLabs, while the 1-kb ladder and pGEM T vector were purchased from Promega. Reverse transcriptase (RT) was from Life Sciences, Inc.

Primers were used without further purification. The library template and corresponding transcribed RNA were purified by denaturing 17\% PAGE. PAGE-purified nucleic acids were visualized by UV shadowing and the products extracted from the gel slice by tumbling overnight in sterile $0.3 \mathrm{M} \mathrm{NaCl}$ at $4^{\circ} \mathrm{C}$. The samples were then concentrated with 2-butanol and were ethanol precipitated. Concentrations were determined by their absorbances at $260 \mathrm{~nm}$ and the corresponding extinction coefficients. Oligonucleotide extinction coefficients were determined using HyTher version 1.0 (Nicolas Peyret and John SantaLucia Jr., Wayne State University, Detroit, MI) (SantaLucia 1998; Peyret et al. 1999). These parameters were calculated using information on the extinction coefficients of nearest neighbors in RNA (Puglisi and Tinoco 1989).

\section{Internal loop library RNA transcription}

The synthetic DNA template for transcription of the internal loop library was created by annealing the following DNA strands: T7 promoter, 5'-TAATACGACTCACTATA; library template + complement to T7 promoter, 5'-CCTTGCGGATCCAATNNNTACTT TCGTANNNATTAAACCCTCTCCCTATAGTGAGTCGTATTA, where $\mathrm{N}$ is an equimolar mixture of $\mathrm{A}, \mathrm{G}, \mathrm{T}$, and $\mathrm{C}$. The internal loop library was synthesized by run-off transcription using T7 RNA polymerase according to the method of Milligan and Uhlenbeck (1989). Reactions were purified as described in general methods. Purity was determined to be $>90 \%$ from analytical kinase experiments.

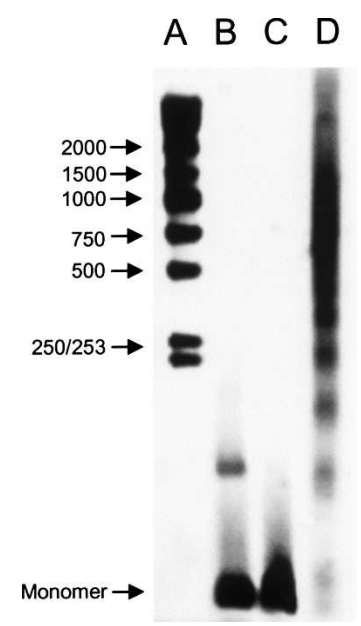

FIGURE 3. Representative gel image of concatenation of BamHIdigested RT-PCR product. Lanes: $(A)$ 1-kb ladder; $(B)$ concatenation of RT-PCR product that was digested with BamHI in solution; $(C)$ monomer; $(D)$ concatenation of RT-PCR product that was digested using our resin-based protocol. 


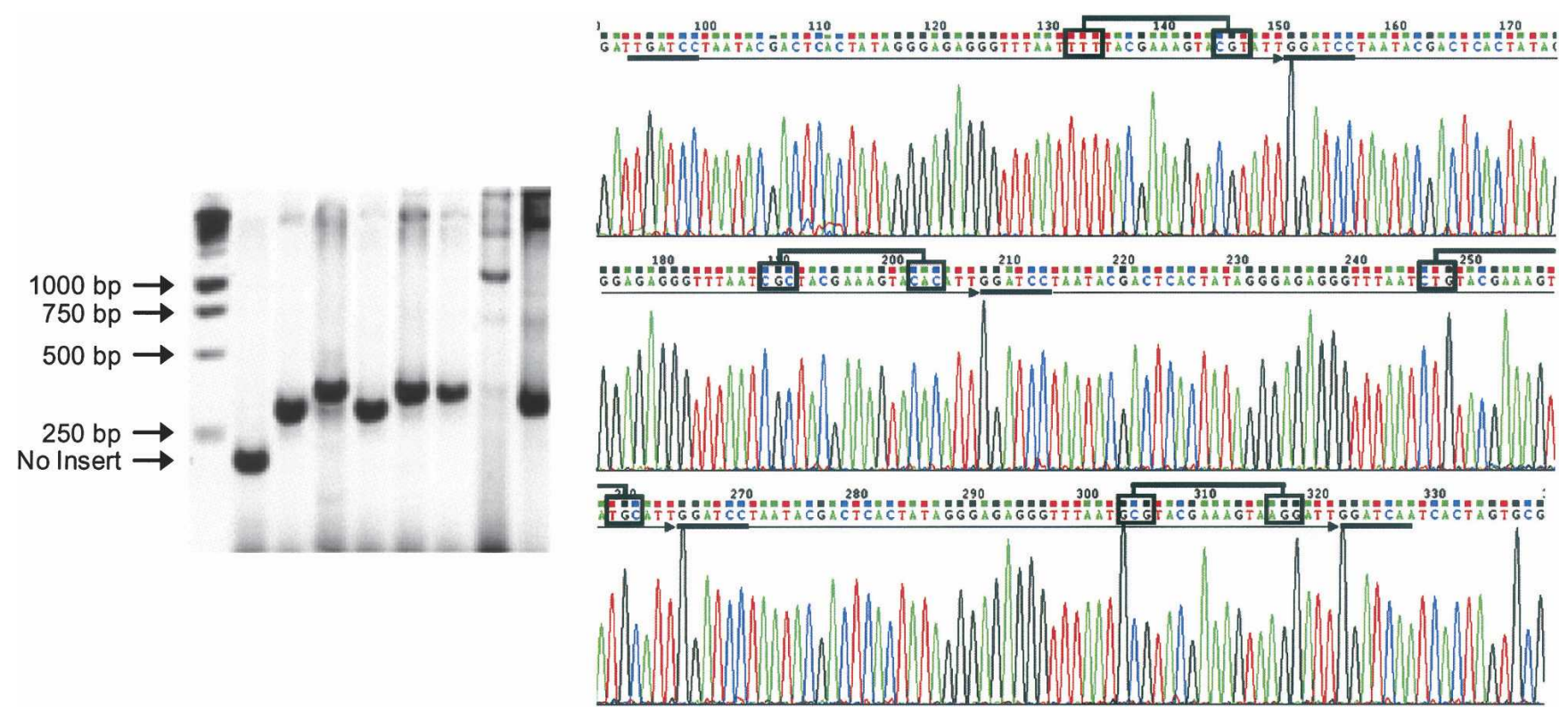

FIGURE 4. (Left) PCR amplification of the cloning site to screen for concatemers. The second lane is the PCR product when no insert is ligated into the vector. (Right) Sequencing chromatogram of a concatemer with four copies of the library. Each copy of the library is underlined with an arrow. BamHI restriction sites are underscored with a heavy line. The randomized nucleotides for library members are boxed and connected with a line.

\section{RT-PCR}

The following primers were used for RT-PCR reactions: PCR primer, 5'-biotin-TTTTTT GGCCGGATCCTAATACGACTCAC TATAGGGAGAGGGTTTAAT, containing a T7 promoter for transcription with T7 RNA polymerase; and RT primer, 5'biotin-TTTTTTCCTTGCGGATCCAAT. The additional Ts were added to the ends of the primer to move the restriction site away farther away from the resin for easier access by the restriction enzyme. The library was amplified via RT-PCR and yielded a product of the appropriate size as determined by PAGE. RT reactions were completed by annealing 1 pmol of the internal loop library RNA and $2 \mu \mathrm{L}$ of $100 \mu \mathrm{M} 5^{\prime}$-biotinylated RT primer for $10 \mathrm{~min}$ at $70^{\circ} \mathrm{C}$ followed by incubation on ice for $10 \mathrm{~min}$. Then $1.6 \mu \mathrm{L}$ of $25 \mathrm{mM}$ dNTPs, $0.8 \mu \mathrm{L}$ of $10 \mathrm{mg} / \mathrm{mL}$ BSA, $4 \mu \mathrm{L}$ of $10 \times \mathrm{RT}$ buffer (provided by the manufacturer), and $0.1 \mu \mathrm{L}$ of $\mathrm{RT}$ or $\mathrm{H}_{2} \mathrm{O}$ for no RT controls were added. The reaction was allowed to proceed for $1 \mathrm{~h}$ at $60^{\circ} \mathrm{C}$, at which point the reaction was quenched by heating for $3 \mathrm{~min}$ at $95^{\circ} \mathrm{C}$. PCR amplification was completed by adding $4 \mu \mathrm{L}$ of $100 \mu \mathrm{M} 5^{\prime}$-biotinylated PCR primer, $2 \mu \mathrm{L}$ of 100 $\mu \mathrm{M} \mathrm{5}$ '-biotinylated RT primer, $0.6 \mu \mathrm{L}$ of $250 \mathrm{mM} \mathrm{MgCl}_{2}, 0.2 \mu \mathrm{L}$ of Taq polymerase, $13 \mu \mathrm{L}$ of $\mathrm{H}_{2} \mathrm{O}$, and $6 \mu \mathrm{L}$ of $10 \times$ PCR buffer to $20 \mu \mathrm{L}$ of the RT reaction. Twenty-five cycles of $95^{\circ} \mathrm{C}$ for $1 \mathrm{~min}$ and $72^{\circ} \mathrm{C}$ for $1 \mathrm{~min}$ were completed. Reactions were analyzed by running an aliquot on a denaturing $17 \%$ polyacrylamide gel that was stained with SYBR gold or ethidium bromide. Only experiments in which the negative controls contained no product were carried on toward subsequent steps. The negative control for RTPCR amplified contained product less than $1 \%$ of the time.

\section{Resin restriction digestion}

Approximately $25 \mu \mathrm{L}$ of the RT-PCR reaction were diluted with $200 \mu \mathrm{L}$ of $1 \times$ PBS and incubated with a twofold excess of the biotin binding capacity of the streptavidin resin $(\sim 20 \mu \mathrm{L}$ of slurry or $10 \mu \mathrm{L}$ of resin). The sample was tumbled for $1 \mathrm{~h}$ at room temperature. The resin was pelleted by centrifugation $(3500 \mathrm{rpm}$ for $1 \mathrm{~min}$ ) and the supernatant removed. The resin was washed with $200 \mu \mathrm{L}$ of $1 \times$ PBS followed by $200 \mu \mathrm{L}$ of $1 \times$ BamHI buffer, pelleting the resin between each step. It was then incubated with $200 \mu \mathrm{L}$ of $1 \times$ BamHI buffer and 10 units of BamHI at $37^{\circ} \mathrm{C}$ for $2 \mathrm{~h}$ with tumbling. The sample was heated for $2 \mathrm{~min}$ to $60^{\circ} \mathrm{C}$, followed by centrifugation to pellet the resin. The supernatant containing only doubly cut RT-PCR product was transferred to a clean microcentrifuge tube. The resin was washed twice with 200 $\mu \mathrm{L}$ of $1 \times \mathrm{PBS}$ and the fractions analyzed by PAGE. Almost all $(\sim 85 \%)$ of the doubly cut RT-PCR product was removed in the BamHI digestion supernatant. Fraction(s) containing cut product were ethanol precipitated with $10 \mu \mathrm{g}$ of glycogen and resuspended in $20 \mu \mathrm{L}$ of DEPC-treated $\mathrm{H}_{2} \mathrm{O}$.

\section{In solution restriction digestion}

A $25 \mu \mathrm{L}$ aliquot of the crude RT-PCR reaction was diluted 10-fold with BamHI buffer and incubated with 10 units of BamHI for $2 \mathrm{~h}$ at $37^{\circ} \mathrm{C}$. Approximately a twofold excess of the biotin binding capacity of the streptavidin resin was added to the restriction digestion reaction. The sample was tumbled for $1 \mathrm{~h}$ at room temperature and the resin removed via centrifugation. Fractions were analyzed by PAGE. The fractions containing DNA were ethanol precipitated with $10 \mu \mathrm{g}$ of glycogen and resuspended in $20 \mu \mathrm{L}$ of DEPC-treated $\mathrm{H}_{2} \mathrm{O}$.

\section{Concatenation of PCR products}

The clean RT-PCR products were annealed in the presence or absence of PEG- 8000 by heating to $95^{\circ} \mathrm{C}$ and slowly cooled to room temperature. Different concentrations of DNA and PEG 
8000 were used to optimize concatenation. The presence of PEG did not appear to significantly improve the amount of concatenation; however, we found the minimum optimal amount of DNA is $1.25 \mu \mathrm{g}$ in the $20 \mu \mathrm{L}$ volume. After slowly cooling to room temperature, T4 DNA ligase buffer and 200 units of T4 DNA ligase were added and the reactions incubated at room temperature overnight. An aliquot of each ligation reaction was analyzed by PAGE. Reactions were carried on to A-tailing and ligation into pGEM T vector. (Unligated monomers, dimers, and some trimers can be removed using an Illustra S-400 HR microspin column [GE Healthcare Life Sciences] per the manufacturer's protocol.)

\section{A-tailing}

The sticky ends of the concatemers were filled in by diluting $10 \mu \mathrm{L}$ of ligation reaction to $50 \mu \mathrm{L}$ in $1 \times$ PCR buffer, $0.3 \mathrm{mM}$ dNTPs, $4.5 \mathrm{mM} \mathrm{MgCl}_{2}$, and $0.1 \mu \mathrm{L}$ of Taq DNA polymerase and incubating for $15 \mathrm{~min}$ at $72^{\circ} \mathrm{C}$. An additional $0.67 \mathrm{mM}$ ATP and $0.75 \mathrm{mM} \mathrm{MgCl}_{2}$ were added, and the reaction was incubated for $15 \mathrm{~min}$ at $72^{\circ} \mathrm{C}$. The reaction was ethanol precipitated and resuspended in $10 \mu \mathrm{L}$ of DEPC-treated $\mathrm{H}_{2} \mathrm{O}$.

\section{Ligation into pGEM T vector}

Ligation was completed per the manufacturer's instructions using $2 \mu \mathrm{L}$ of the reaction after A-tailing. Ligation was allowed to proceed overnight at room temperature. Approximately $100 \mu \mathrm{L}$ of chemically competent JM109 E. coli was transformed with $5 \mu \mathrm{L}$ of the ligation reaction. Cells were plated onto LB agar plates containing $50 \mathrm{mg} / \mathrm{L}$ ampicillin, IPTG, and X-gal.

\section{Sequencing reactions}

White colonies were used to inoculate $2.5 \mathrm{~mL}$ of LB media containing $50 \mathrm{mg} / \mathrm{L}$ ampicillin, and the cultures were grown overnight at $37^{\circ} \mathrm{C}$. Plasmids were isolated using an Eppendorf fast plasmid mini kit. We analyzed 22 clones for the presence of concatemers by PCR amplification of the cloning site using M13 primers and 25 cycles of $30 \mathrm{sec}$ at $95^{\circ} \mathrm{C} / 30 \mathrm{sec}$ at $50^{\circ} \mathrm{C} / 1 \mathrm{~min}$ at $72^{\circ} \mathrm{C}$. Products were separated on a $2 \%$ agarose gel. Sequencing reactions were completed at Roswell Park Cancer Institute's Sequencing Facility.

\section{ACKNOWLEDGMENTS}

We thank the New York State Center for Excellence in Bioinformatics and Life Sciences, The University at Buffalo, the Camille and Henry Dreyfus New Faculty Award (to M.D.D.), and the JD Watson NYSTAR Young Investigator Award (to M.D.D.) for funding.

Received March 21, 2007; accepted October 15, 2007.

\section{REFERENCES}

Albertini, A.M., Hofer, M., Calos, M.P., and Miller, J.H. 1982. On the formation of spontaneous deletions: The importance of short sequence homologies in the generation of large deletions. Cell 29: 319-328.

Bessho, Y., Hodgson, D.R., and Suga, H. 2002. A tRNA aminoacylation system for non-natural amino acids based on a programmable ribozyme. Nat. Biotechnol. 20: 723-728.
Bevilacqua, J.M. and Bevilacqua, P.C. 1998. Thermodynamic analysis of an RNA combinatorial library contained in a short hairpin. Biochemistry 37: 15877-15884.

Childs-Disney, J.L., Wu, M., Pushechnikov, A., Aminova, O., and Disney, M.D. 2007. A small molecule microarray platform to select RNA internal loop-ligand interactions. ACS Chem. Biol. 2: 745754.

Disney, M.D. and Childs-Disney, J.L. 2007. Using selection to identify and chemical microarray to study the RNA internal loops recognized by $6^{\prime}$-N-acylated kanamycin A. ChemBioChem 8: 649-656.

Ellington, A.D. and Szostak, J.W. 1990. In vitro selection of RNA molecules that bind specific ligands. Nature 346: 818-822.

Gold, L. 2002. RNA as the catalyst for drug screening. Nat. Biotechnol. 20: $671-672$.

Hartig, J.S., Najafi-Shoushtari, S.H., Grune, I., Yan, A., Ellington, A.D., and Famulok, M. 2002. Protein-dependent ribozymes report molecular interactions in real time. Nat. Biotechnol. 20: $717-722$.

Jenison, R.D., Gill, S.C., Pardi, A., and Polisky, B. 1994. Highresolution molecular discrimination by RNA. Science 263: 14251429.

Jones, I., Primrose, S.B., and Erlich, S.D. 1982. Recombination between short direct repeats in a RecA host. Mol. Gen. Genet. 188: 486-489.

Milligan, J.F. and Uhlenbeck, O.C. 1989. Synthesis of small RNAs using T7 RNA polymerase. Methods Enzymol. 180: 51-62.

Nakano, M., Moody, E.M., Liang, J., and Bevilacqua, P.C. 2002. Selection for thermodynamically stable DNA tetraloops using temperature gradient gel electrophoresis reveals four motifs: $\mathrm{d}(\mathrm{cGNNAg}), \mathrm{d}(\mathrm{cGNABg}), \mathrm{d}(\mathrm{cCNNGg})$, and $\mathrm{d}(\mathrm{gCNNGc})$. Biochemistry 41: 14281-14292.

Pagratis, N.C. 1996. Rapid preparation of single stranded DNA from PCR products by streptavidin induced electrophoretic mobility shift. Nucleic Acids Res. 24: 3645-3646. doi: 10.1093/nar/ 24.18.3645.

Peyret, N., Seneviratne, P.A., Allawi, H.T., and SantaLucia Jr., J. 1999. Nearest-neighbor thermodynamics and NMR of DNA sequences with internal $\mathrm{A} \cdot \mathrm{A}, \mathrm{C} \cdot \mathrm{C}, \mathrm{G} \cdot \mathrm{G}$, and $\mathrm{T} \cdot \mathrm{T}$ mismatches. Biochemistry 38: $3468-3477$.

Proctor, D.J., Schaak, J.E., Bevilacqua, J.M., Falzone, C.J., and Bevilacqua, P.C. 2002. Isolation and characterization of a family of stable RNA tetraloops with the motif YNMG that participate in tertiary interactions. Biochemistry 41: 12062-12075.

Puglisi, J.D. and Tinoco Jr., I. 1989. Absorbance melting curves of RNA. Methods Enzymol. 180: 304-325.

Robertson, D.L. and Joyce, G.F. 1990. Selection in vitro of an RNA enzyme that specifically cleaves single-stranded DNA. Nature 344: $467-468$.

Sanger, F. 1981. Determination of nucleotide sequences in DNA. Science 214: 1205-1210.

SantaLucia Jr., J. 1998. A unified view of polymer, dumbbell, and oligonucleotide DNA nearest-neighbor thermodynamics. Proc. Natl. Acad. Sci. 95: 1460-1465.

Seetharaman, S., Zivarts, M., Sudarsan, N., and Breaker, R.R. 2001. Immobilized RNA switches for the analysis of complex chemical and biological mixtures. Nat. Biotechnol. 19: 336-341.

Shu, Z. and Bevilacqua, P.C. 1999. Isolation and characterization of thermodynamically stable and unstable RNA hairpins from a triloop combinatorial library. Biochemistry 38: 15369-15379.

Szostak, J.W., Bartel, D.P., and Luisi, P.L. 2001. Synthesizing life. Nature 409: 387-390.

Tuerk, C. and Gold, L. 1990. Systematic evolution of ligands by exponential enrichment: RNA ligands to bacteriophage T4 DNA polymerase. Science 249: 505-510.

Velculescu, V.E., Zhang, L., Vogelstein, B., and Kinzler, K.W. 1995. Serial analysis of gene expression. Science 270: 484-487. 

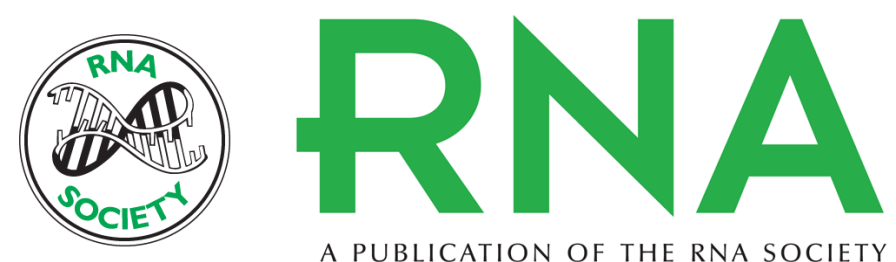

A PUBLICATION OF THE RNA SOCIETY

\section{A simple ligation-based method to increase the information density in sequencing reactions used to deconvolute nucleic acid selections}

Jessica L. Childs-Disney and Matthew D. Disney

RNA 2008 14: 390-394

References This article cites 24 articles, 5 of which can be accessed free at:

http://rnajournal.cshlp.org/content/14/2/390.full.html\#ref-list-1

License

Email Alerting Receive free email alerts when new articles cite this article - sign up in the box at the Service top right corner of the article or click here. 